\title{
Effects of maintaining eucalcemia following immunoactivation in lactating Holstein dairy cows
}

\author{
E. A. Horst, E. J. Mayorga, M. Al-Qaisi, M. A. Abeyta, S. L. Portner, C. S. McCarthy, B. M. Goetz, S. K. Kvidera, \\ and L. H. Baumgard* \\ Department of Animal Science, lowa State University, Ames 50011
}

\section{ABSTRACT}

Periparturient hypocalcemia is a common metabolic disorder and it is ostensibly associated with negative health and production outcomes. Acute infection also markedly decreases circulating $\mathrm{Ca}$, but the reasons for and consequences of it on physiological and immunological parameters are unknown. Objectives were to evaluate the effects of maintaining eucalcemia on production, metabolic, and immune variables following an intravenous lipopolysaccharide (LPS) challenge. Twelve multiparous lactating Holstein cows $(717 \pm 20 \mathrm{~kg}$ of body weight; $176 \pm 34 \mathrm{~d}$ in milk; parity $3 \pm 0.2)$ were enrolled in a study containing 2 experimental periods (P); during P1 (3 d), cows consumed feed ad libitum and baseline values were obtained. At the initiation of P2 (4 d), cows were randomly assigned to 1 of 2 treatments: (1) LPS administered (LPS-Con; $0.5 \mu \mathrm{g} / \mathrm{kg}$ of body weight LPS; $\mathrm{n}=6$ ) or (2) LPS administered + eucalcemic clamp (LPS-Ca; $0.5 \mu \mathrm{g} / \mathrm{kg}$ of body weight LPS; Ca infusion; $\mathrm{n}=6$ ). Cows were fasted for the first $12 \mathrm{~h}$ during P2. After LPS administration, ionized Ca was determined every 15 min for $6 \mathrm{~h}$ and every 30 min for an additional $6 \mathrm{~h}$ and intravenous $\mathrm{Ca}$ infusion was adjusted in LPS-Ca cows to maintain eucalcemia. Blood ionized Ca was decreased $23 \%$ for the first $12 \mathrm{~h}$ postbolus in LPS-Con cows, and by design, Ca infusion prevented hypocalcemia. To maintain eucalcemia for the $12 \mathrm{~h}, 13.7 \mathrm{~g}$ of Ca was infused. The total Ca deficit (including Ca not secreted into milk) accumulated over the $12 \mathrm{~h}$ was 10.4 and $20.2 \mathrm{~g}$ for the LPS-Con and LPSCa treatments, respectively. Mild hyperthermia $\left(0.8^{\circ} \mathrm{C}\right)$ occurred for $\sim 6 \mathrm{~h}$ post-LPS administration relative to P1. From 6 to $7 \mathrm{~h}$ postbolus rectal temperature from LPS-Ca cows was increased $\left(0.6^{\circ} \mathrm{C}\right)$ relative to LPS-Con cows. On d 1 of P2, milk yield decreased $(61 \%)$ in both treatments relative to P1. Relative to LPS-Con cows,

Received January 27, 2020.

Accepted March 20, 2020.

*Corresponding author: baumgard@iastate.edu milk yield decreased (15\%) in LPS-Ca cows during P2. Overall, circulating LPS-binding protein continuously increased postbolus, and at $24 \mathrm{~h}$ LPS-binding protein levels in LPS-Ca cows were increased (80\%) relative to LPS-Con cows. During P2, serum amyloid A increased (4-fold) in both treatments relative to P1. Administering LPS initially decreased circulating neutrophils, then cell counts progressively increased with time. Calcium infusion decreased neutrophil counts (40\%) from 9 to $12 \mathrm{~h}$ postbolus relative to LPS-Con cows. Neutrophil function, as assessed by oxidative burst and myeloperoxidase production, did not differ due to treatment. In summary, maintaining eucalcemia (via intravenous Ca infusion) during an immune challenge appeared to intensify inflammation and adversely affect lactation performance.

Key words: calcium, endotoxin, inflammation, infection

\section{INTRODUCTION}

At the onset of lactation, the mammary gland's use of plasma $\mathrm{Ca}$ is so extensive that it often exceeds the capacity of homeostatic mechanisms (i.e., parathyroid hormone and vitamin D) to replenish it and, consequently, cows develop clinical or subclinical hypocalcemia (SCH; Horst et al., 2005; Goff, 2008). Hypocalcemia has been loosely associated with reduced milk production and increased disease incidence (Chapinal et al., 2011; Martinez et al., 2012, 2014; Venjakob et al., 2018) and is believed to be a causative factor in periparturient immunosuppression (Ducusin et al., 2003; Kimura et al., 2006; Martinez et al., 2012, 2014). Despite the purported immune "dysfunction," nearly all transition cows (even seemingly healthy ones) experience some degree of inflammation postpartum (Humblet et al., 2006). The magnitude and persistency of the inflammatory state appears dependent on the frequency and type of immune insults (Bertoni et al., 2008; Bradford et al., 2015; Trevisi and Minuti, 2018) and is predictive of transition cow performance (Ohtsuka et al., 2001; Ametaj et al., 2005, 2010; Abuajamieh et al., 2016). 
Interestingly, independent of the transition period, immune activation decreases circulating $\mathrm{Ca}$ and the response is conserved across species including humans (Cardenas-Rivero et al., 1989; Dias et al., 2013), calves (Tennant et al., 1973; Elsasser et al., 1996), dogs (Holowaychuk et al., 2012), horses (Toribio et al., 2005), pigs (Carlstedt et al., 2000), and sheep (Naylor and Kronfeld, 1986). We and others have repeatedly demonstrated LPS-induced hypocalcemia in lactating cows (Griel et al., 1975; Waldron et al., 2003; Kvidera et al., 2017; Horst et al., 2018). Thus, because most periparturient cows are inflamed, immunoactivation may be contributing (at least to some extent) to hypocalcemia during the transition period, a theory originally proposed by early investigators (Thomas, 1889; Hibbs, 1950). Inflammation's effect on Ca homeostasis may explain why SCH remains common, despite successfully implementing pre-partum prophylactic and therapeutic strategies (i.e., acidifying rations, low $\mathrm{Ca}$ diets, $\mathrm{Ca}$ chelators, and so on) aimed at preventing milk fever (Reinhardt et al., 2011).

Postcalving oral Ca supplementation is an additional approach to mitigate SCH (Oetzel and Miller, 2012; Oetzel, 2013). Aside from improving plasma $\mathrm{Ca}$ concentrations and despite some inconsistencies (Domino et al., 2017), oral Ca boluses have been shown to improve milk production and some health metrics (Oetzel, 1996; Oetzel and Miller, 2012). We recently demonstrated that oral $\mathrm{Ca}$ (in combination with live yeast) before and following LPS administration ameliorates hypocalcemia (although it did not prevent it) and improves production (feed intake and milk yield) performance (Al-Qaisi et al., 2020). Unfortunately, we were unable to distinguish the effects of $\mathrm{Ca}$ and live yeast; however, considering the presumed role of $\mathrm{Ca}$ in immune function and transition cow performance, we conjectured the beneficial effects of the oral bolus were primarily due to alleviating hypocalcemia. Therefore, we hypothesized that maintaining eucalcemia during immunoactivation in lactating dairy cows would improve production and inflammatory outcomes. Study objectives were to evaluate the effects of preventing hypocalcemia on production parameters, inflammatory biomarkers, and neutrophil function in intensely immune-activated lactating dairy cows.

\section{MATERIALS AND METHODS}

\section{Animals and Experimental Design}

All procedures were approved by the Iowa State University Institutional Animal Care and Use Committee. Twelve nonpregnant lactating Holstein cows $(717 \pm 20$ $\mathrm{kg}$ of BW; $176 \pm 34$ DIM; parity $3 \pm 0.2$; SE) were housed in individual box-stalls $(4.57 \times 4.57 \mathrm{~m})$ at the Iowa State University Dairy Farm (Ames). Cows were allowed $3 \mathrm{~d}$ to acclimate during which they were implanted with bilateral jugular catheters. Cows were fed ad libitum once daily $(0600 \mathrm{~h})$ with a diet formulated to meet or exceed the predicted requirements (NRC, 2001) of energy, protein, minerals, and vitamins (Table 1). Cows were milked twice daily (0600 and $1800 \mathrm{~h}$ ) throughout the experiment and yield was recorded. A sample for composition analysis (milk fat, protein, lactose, MUN, and SCC) was obtained at each milking and stored at $4^{\circ} \mathrm{C}$ with a preservative (bronopol tablet, D \& F Control System, San Ramon, CA) until analysis by Dairy Lab Services (Dubuque, IA) using AOACapproved infrared analysis equipment and procedures (AOAC International, 1995). Additional milk samples were collected and stored at $-20^{\circ} \mathrm{C}$ until analysis by the Iowa State University Veterinary Diagnostic Lab (Ames) for total Ca concentrations using inductively coupled plasma MS (Analytic Jena Inc., Woburn, MA). Rectal temperature was measured using a digital thermometer (GLA M700 Digital Thermometer, San Luis Obispo, CA) and recorded after each milking.

The trial consisted of 2 experimental periods; P1 lasted $3 \mathrm{~d}$ and served as the baseline, which yielded data for covariate analysis. During P2, which lasted 4 $\mathrm{d}$, animals were randomly assigned to 1 of 2 intravenous bolus treatments: (1) LPS administered in which hypocalcemia was allowed to develop (LPS-Con; $0.5 \mu \mathrm{g} /$

Table 1. Ingredients and composition of $\operatorname{diet}^{1}$

\begin{tabular}{lc}
\hline Item $^{2}$ & Value \\
\hline Ingredient (\% of DM) & \\
Corn silage & 21.4 \\
Alfalfa hay & 4.1 \\
Baleage & 16.4 \\
Ground corn & 29.7 \\
Corn gluten feed & 9.4 \\
SoyPlus ${ }^{3}$ & 2.6 \\
Soybean meal & 5.9 \\
Whole cottonseed & 3.6 \\
Molasses & 1.8 \\
CP mix & 5.1 \\
Chemical analysis (\% of DM) & \\
Starch & 27.9 \\
CP & 17.2 \\
NDF & 29.2 \\
ADF & 18.4 \\
NE & 1 Mcal/kg of DM) \\
\hline
\end{tabular}

${ }^{1}$ Values represent an average of ration nutrient summary reports collected throughout the trial. Diet moisture averaged $51.8 \%$.

${ }^{2}$ Average nutrient levels: $4.86 \%$ fat, $0.95 \%$ Ca, $0.43 \% \mathrm{P}, 0.36 \% \mathrm{Mg}$, $0.23 \% \mathrm{~S}, 1.38 \% \mathrm{~K}, 0.49 \% \mathrm{Na}, 0.65 \% \mathrm{Cl}, 88.06 \mathrm{mg} / \mathrm{kg} \mathrm{Zn}, 51.31 \mathrm{mg} / \mathrm{kg}$ $\mathrm{Mn}, 4.06 \mathrm{mg} / \mathrm{kg} \mathrm{Fe}, 15.64 \mathrm{mg} / \mathrm{kg} \mathrm{Cu}, 0.87 \mathrm{mg} / \mathrm{kg} \mathrm{Co}, 0.19 \mathrm{mg} / \mathrm{kg} \mathrm{Se}$, $0.87 \mathrm{mg} / \mathrm{kg} \mathrm{I}, 6,810.1 \mathrm{IU} / \mathrm{kg}$ vitamin $\mathrm{A}, 643.6 \mathrm{IU} / \mathrm{kg}$ vitamin $\mathrm{D}$, and $18.9 \mathrm{IU} / \mathrm{kg}$ vitamin $\mathrm{E}$.

${ }^{3}$ Mechanically processed soybean meal, Dairy Nutrition Plus, Ralston, IA. 
$\mathrm{kg}$ of BW of LPS; $\mathrm{n}=6$ ) and (2) LPS administered in which eucalcemia was maintained (LPS-Ca; $0.5 \mu \mathrm{g} / \mathrm{kg}$ of BW of LPS; Ca infusion; $\mathrm{n}=6$ ). Lipopolysaccharide (Escherichia coli O55:B5; Sigma-Aldrich, St. Louis, MO) was dissolved in sterile saline at a concentration of $89.6 \mu \mathrm{g} / \mathrm{mL}$ and passed through a $0.2-\mu \mathrm{m}$ sterile syringe filter (Thermo Scientific, Waltham, MA). The total volume of LPS solution administered i.v. was approximately $4 \mathrm{~mL}$. Each respective treatment bolus was administered immediately following the AM milking and 0 min blood sample collection. In the LPS-Ca treatment, we performed a eucalcemic clamp, where a 23\% Ca gluconate solution (Agri Laboratories Ltd., St. Joseph, MO) was i.v. infused at a known and adjustable rate utilizing a modular pump (Deltec 3000, Deltec Inc., St. Paul, MN) to maintain the pre-LPS administration blood iCa concentrations ( $\pm 10 \%$ of baseline). To ensure infusion rate accuracy, $250 \mathrm{~mL}$ of the Ca gluconate solution was further diluted in $750 \mathrm{~mL}$ of sterile saline. Cows were tethered during the 12-h challenge period (but allowed to stand up and lay down) to allow for frequent sampling. Water was provided ad libitum and feed was removed from all cows $\sim 0.5 \mathrm{~h}$ before treatment administration. Animals remained fasted during the 12-h data collection period to eliminate the confounding effect of dissimilar nutrient intake.

To establish baseline iCa levels, blood samples were obtained at -30 and 0 min relative to LPS administration and immediately analyzed using an iSTAT handheld machine and cartridge (CG8+, Abbott Point of Care, Princeton, NJ). Blood iCa was measured hourly for LPS-Con cows. For cows in the LPS-Ca treatment, blood samples were obtained every $15 \mathrm{~min}$ for the first $6 \mathrm{~h}$ and every $30 \mathrm{~min}$ for the next $6 \mathrm{~h}$ thereafter. Ionized Ca infusion began when blood iCa content declined below baseline concentrations. The rate of Ca infusion (ROCI) was transformed from $\mathrm{mL} / \mathrm{h}$ to $\mathrm{g} / \mathrm{h}$. The total Ca infused for each cow was calculated using the ROCI for each interval (36 intervals in total) according to the following equation, where $i$ is an index of time:

$$
\begin{aligned}
& \sum_{i=0}^{24} \operatorname{ROCI}(\mathrm{g} / \mathrm{h})_{i} \times \frac{1 \mathrm{~h}}{60 \min } \times 15 \mathrm{~min} \\
& +\sum_{i=0}^{12} \operatorname{ROCI}(\mathrm{g} / \mathrm{h})_{i} \times \frac{1 \mathrm{~h}}{60 \mathrm{~min}} \times 30 \mathrm{~min} .
\end{aligned}
$$

Milk total Ca content was assessed at the AM and PM milkings on d 1 of P2 and analyzed for total Ca concentrations. Additional plasma samples were collected from all treatments daily at $0600 \mathrm{~h}$ during $\mathrm{P} 1$ and at $-0.5,0,6,12,24,48$, and $96 \mathrm{~h}$ relative to bolus administration during P2. Plasma was harvested following centrifugation at $1,500 \times g$ for $15 \mathrm{~min}$ at $4^{\circ} \mathrm{C}$ and was subsequently frozen at $-20^{\circ} \mathrm{C}$ until analysis.

Plasma insulin, glucagon, nonesterified fatty acids (NEFA), BHB, BUN, LPS-binding protein (LBP), and serum amyloid A (SAA) concentrations were determined using commercially available kits according to the manufacturers' instructions (insulin, Mercodia AB, Uppsala, Sweden; Glucagon, RD Systems Inc., Minneapolis, MN; NEFA, Wako Chemicals USA, Richmond, VA; BHB, Pointe Scientific Inc., Canton, MI; BUN Teco Diagnostics, Anaheim, CA; LBP, Hycult Biotech, Uden, the Netherlands; SAA, Tridelta Development Ltd., Kildare, Ireland). The inter- and intraassay coefficients of variation for insulin, glucagon, NEFA, BHB, BUN, LBP, and SAA were 4.3 and $6.0 \%, 10.5$ and $14.1 \%, 3.0$ and $3.6 \%, 4.2$ and $7.1 \%, 3.4$ and $3.6 \%, 11.3$ and $8.6 \%$, and 22.3 and $5.3 \%$, respectively. For complete blood count analysis, a $3-\mathrm{mL}$ blood sample was collected at $0,1,2,3,4,5,6,9,12,24,36,48,72$, and $96 \mathrm{~h}$ relative to bolus administration (K2EDTA, BD Franklin Lakes, $\mathrm{NJ}$ ) and stored at $4^{\circ} \mathrm{C}$ for $\sim 12 \mathrm{~h}$ before submission to the Iowa State University's Department of Veterinary Pathology.

\section{PMN Isolation and Function}

Blood samples $(32 \mathrm{~mL})$ for neutrophil isolation were collected on d 4 of $\mathrm{P} 1$, and at $6,12,24$, and $48 \mathrm{~h}$ post-LPS administration into $50-\mathrm{mL}$ conical tubes containing acid citrate dextrose $(8 \mathrm{~mL})$. Samples were immediately transported to the laboratory for neutrophil isolation as previously described (Kimura et al., 2014). In brief, samples were centrifuged at 1,000 $\times g$ for 20 min at room temperature and the plasma, buffy coat, and upper portion of the packed red blood cell pellet were removed. The remaining red blood cells were lysed twice using hypotonic phosphate-buffered deionized water, and neutrophils were pelleted following centrifugation at $300 \times g$ for $5 \mathrm{~min}$ at $23^{\circ} \mathrm{C}$. Neutrophils were resuspended in PBS and standardized to $5.0 \times 10^{7}$ cells/mL. Neutrophil function was assessed by extracellular release of myeloperoxidase (MPO) and oxidative burst (cytochrome $\mathrm{C}$ reduction) using methods previously described by Kimura et al. (2014).

To assess oxidative burst, $2.5 \times 10^{6}$ neutrophils were treated with either Hanks' balanced salt solution (HBSS) or HBSS plus phorbol myristate acetate followed by treatment with cytochrome C. Cells were incubated at $39^{\circ} \mathrm{C}$ for 15 min and immediately read at 2 wavelengths (550 and $650 \mathrm{~nm}$ ) using a spectrophotometer.

Three cell preparations were used to assess MPO activity: (1) cells were lysed by treatment with cetyltrimethylammonium bromide solution as a measure of 
total MPO, (2) PMN were stimulated with equal parts Ca ionophore A23187 and cytochalasin B in HBSS to assess release of MPO with stimulation, and (3) PMN treated with HBSS alone as a measure of unstimulated MPO release. Each preparation was loaded with 1.25 $\times 10^{6}$ cells in a microtiter plate and incubated at $39^{\circ} \mathrm{C}$ for $20 \mathrm{~min}$. Following incubation, $50 \mu \mathrm{L} /$ well of $3,3^{\prime}$, 5,5'-tetramethylbenzidine dihydrochloride was added $(3.25 \mathrm{mM})$ followed promptly with $50 \mu \mathrm{L} /$ well of $\mathrm{H}_{2} \mathrm{O}_{2}$. The reaction was stopped after a 2-min incubation with the addition of $50 \mu \mathrm{L} /$ well $2 \mathrm{~N} \mathrm{H}_{2} \mathrm{SO}_{4}$. Plates were centrifuged for $1 \mathrm{~min}$ at $600 \times g$ at $23^{\circ} \mathrm{C}$, and the supernatant was transferred to a second plate. Optical density (OD) was determined at $405 \mathrm{~nm}$ using a spectrophotometer. Percentage of MPO released from PMN was determined using the following equation:

$$
\begin{gathered}
\text { exocytosis }(\%)=[(\mathrm{OD} \text { of stimulated PMN }) / \\
(\mathrm{OD} \text { of lysed PMN })] \times 100
\end{gathered}
$$

\section{Calculations and Statistical Analysis}

Administering LPS decreases milk yield and therefore decreases Ca uptake by the mammary gland for milk synthesis. The decrease in milk yield permitted us to estimate the amount of Ca conserved (milk Ca deficit) in cows administered LPS and allowed to develop hypocalcemia and those maintained at eucalcemia. Total Ca output in milk before the challenge was calculated to establish a baseline. Milk Ca content at $12 \mathrm{~h}$ was subtracted from the baseline to calculate the milk Ca deficit. For LPS-Con cows, milk Ca deficit was used solely to calculate the total Ca deficit. For LPS-Ca cows, milk $\mathrm{Ca}$ deficit plus the amount of $\mathrm{Ca}$ infused to maintain eucalcemia were combined to obtain the total $\mathrm{Ca}$ deficit, and this approach is similar to how we calculated the glucose deficit in our previous LPSeuglycemic clamp papers (Kvidera et al., 2017; Horst et al., 2018, 2019).

Sample size determination (6 animals/treatment) was based on previous reports and logistical constraints (Horst et al., 2019; Al-Qaisi et al., 2020). Post-hoc power analysis (PROC POWER, SAS Inst. Inc., Cary, NC) based on the results of our primary objective (ionized $\mathrm{Ca}$ ) indicated a statistical power of $>90 \%(\alpha=0.05)$. Each animal's respective parameter was analyzed using a repeated measures ANOVA with an autoregressive covariance structure for milk yield, DMI, and milk composition and a spatial power law covariance structure for blood metabolites, inflammatory biomarkers, neutrophil function assays, complete blood count, iSTAT, and rectal temperature data. The repeated effect was time relative to LPS administra- tion. Each specific variable's pre-bolus values (i.e., P1 average or $0 \mathrm{~h}$ when available) served as a covariate for analysis of P2. Effects of treatment, time (h or d relative to bolus administration), and treatment $\times$ time interactions were assessed as a completely randomized design using PROC MIXED (SAS Inst. Inc.). To evaluate effects of LPS administration, a separate analysis (using the same model) was used to make statistical comparisons with baseline (pre- vs. post-LPS) in which the average P1 value (DMI, milk yield, and neutrophil function) or $0 \mathrm{~h}$ (rectal temperature and blood variables) for each parameter was included as an additional time point. Data are reported as least squares means and considered significant if $P \leq 0.05$ and a tendency if $0.05<P \leq 0.10$.

\section{RESULTS}

\section{Calcium and Blood Gas Analysis}

Administering LPS decreased blood iCa (23\%) for the first $12 \mathrm{~h}$ postbolus in LPS-Con cows and, by design, $\mathrm{Ca}$ infusion prevented hypocalcemia in LPS-Ca cows $(P<0.01$; Figure 1). Collectively, $13.7 \mathrm{~g}$ of Ca was infused to maintain eucalcemia during the 12-h clamp. Milk Ca concentrations averaged $1.24 \pm 0.04$ and 0.94 \pm 0.04 at the AM milking and $1.55 \pm 0.13$ and $1.71 \pm$ 0.09 at the PM milking for LPS-Con and LPS-Ca cows, respectively. Milk yield averaged 18.1 and $20.2 \mathrm{~kg}$ at the AM milking and 7.3 and $7.9 \mathrm{~kg}$ at the PM milking for LPS-Con and LPS-Ca cows, respectively. The total Ca deficit accumulated over the $12 \mathrm{~h}$ was 10.4 and 20.2 $\mathrm{g}$ for the LPS-Con and LPS-Ca treatments, respectively. During P2, Ca infusion increased $\mathrm{HCO}_{3}$, base excess, and $\mathrm{pH}$ relative to LPS-Con cows $(P \leq 0.03$; Supplemental Table S1; https://doi.org/10.3168/jds $.2020-18268)$. Mild hyperthermia $\left(0.8^{\circ} \mathrm{C}\right)$ was observed for $\sim 5.5 \mathrm{~h}$ post-LPS administration relative to $\mathrm{P} 1(P$ $\leq 0.05)$. From 6 to $7 \mathrm{~h}$ postbolus, rectal temperature in LPS-Ca cows increased $\left(0.6^{\circ} \mathrm{C}\right)$ relative to LPS-Con cows $(P<0.01 ;$ Figure $2 \mathrm{~A})$.

\section{Production Metrics}

Overall, DMI did not differ between treatments $(P$ $>0.25$ ); however, hypophagia was observed for $2 \mathrm{~d}$ postbolus relative to baseline (34 and $45 \%$ for LPS-Con and LPS-Ca, respectively; $P<0.01$; Figure 2B). On d 3 postbolus, DMI in LPS-Ca cows tended to remain below baseline $(15 \% ; P=0.07)$, whereas it returned to pre-LPS infusion levels in LPS-Con cows (Figure 2B). Relative to baseline, milk yield decreased (45\%) in both treatments for the first $2 \mathrm{~d}$ postbolus ( $61 \%$ on $\mathrm{d} 1$ and $29 \%$ on d $2 ; P<0.01$; Figure $2 \mathrm{C}$ ). Overall during P2, 
milk yield from LPS-Ca cows tended to be decreased $(15 \%)$ relative to LPS-Con cows $(P=0.07$; Figure $2 \mathrm{C})$ and was decreased on d 1 of P2 $(37 \% ; P=0.04$; Figure $2 \mathrm{C})$. Milk lactose content decreased in both treatments postbolus, but the magnitude of decrease was greater in LPS-Ca cows relative to LPS-Con $(P<0.01$; Table $2)$. Milk lactose gradually returned to baseline in both treatments with time $(P<0.01)$. Milk fat, protein, and MUN content increased in both treatments at $24 \mathrm{~h}$ following LPS administration $(P<0.01)$. From 12 to 24 $\mathrm{h}$ milk fat, protein, and MUN content were increased in LPS-Ca compared with LPS-Con cows $(26,11$, and $17 \%$, respectively; $P \leq 0.05$; Table 2 ). Milk SCC did not differ due to treatment $(P>0.24$; Table 2$)$.

\section{Metabolic Variables}

Regardless of treatment, administering LPS increased circulating glucose for $2 \mathrm{~h}$ postbolus relative to P1 (28\%; $P<0.05)$, after which hypoglycemia developed (Figure 3A). Glucose concentrations returned to baseline at $24 \mathrm{~h}$ postbolus. Relative to $\mathrm{P} 1$, insulin concentrations increased post-LPS $(60 \%)$ similarly among treatments $(P \leq 0.04$; Figure $3 \mathrm{~B})$. Overall, circulating glucagon increased for $12 \mathrm{~h}$ postbolus, then gradually decreased below baseline with time $(P=0.04$; Figure $3 \mathrm{C}$ ) and was unaffected by Ca infusion. Regardless of infusing Ca, NEFA concentrations increased (3-fold, relative to $\mathrm{P} 1 ; P<0.01)$ at $12 \mathrm{~h}$ postbolus, then progressively decreased with time $(P<0.01$; Figure $4 \mathrm{~A})$. Administering LPS decreased circulating BHB (33\%, relative to $\mathrm{P} 1$ ) for $12 \mathrm{~h}$ postbolus, after which levels returned to baseline $(P \leq 0.05)$. At $48 \mathrm{~h}$ postbolus, BHB concentrations from LPS-Ca cows tended to be decreased $(20 \%)$ relative to controls $(P=0.07$; Figure $4 \mathrm{~B})$. Blood urea nitrogen increased ( $41 \%$ for first $24 \mathrm{~h}$; $P \leq 0.01)$ similarly in both treatments postbolus relative to P1. Throughout P2, BUN concentrations from LPS-Ca cows increased (8\%) relative to LPS-Con cows $(P=0.05 ;$ Figure $4 \mathrm{C})$.

\section{Inflammatory Biomarkers and Immune Metrics}

Overall during P2, circulating LBP and SAA increased post-LPS administration (3- and 4-fold, respectively; $P<0.01$; Figure $5 \mathrm{~A}$ and $5 \mathrm{~B}$ ) relative to $\mathrm{P} 1$. At $24 \mathrm{~h}$ postbolus, circulating LBP from LPS-Ca cows increased $(80 \%)$ relative to controls $(P=0.02$; Figure 5A). Lipopolysaccharide administration initially decreased $(66 \%$ for $12 \mathrm{~h}$ ) circulating WBC then they progressively increased with time $(33 \%$ from 24 to $48 \mathrm{~h}$ relative to baseline; $P<0.01$ ). Circulating monocytes and lymphocytes initially decreased following LPS administration and gradually increased with time $(P<$ 0.01). Maintaining eucalcemia had no effect on circulating WBC, monocytes, or lymphocytes (Table 3). The pattern of circulating neutrophils reflected the WBC, however, from 9 to $12 \mathrm{~h}$ postbolus neutrophils from LPS-Ca cows were decreased $(40 \%)$ relative to LPSCon $(P \leq 0.05$; Figure $5 \mathrm{C})$. During P2, there were no overall treatment effects on neutrophil oxidative burst. However, when compared with P1, oxidative burst from

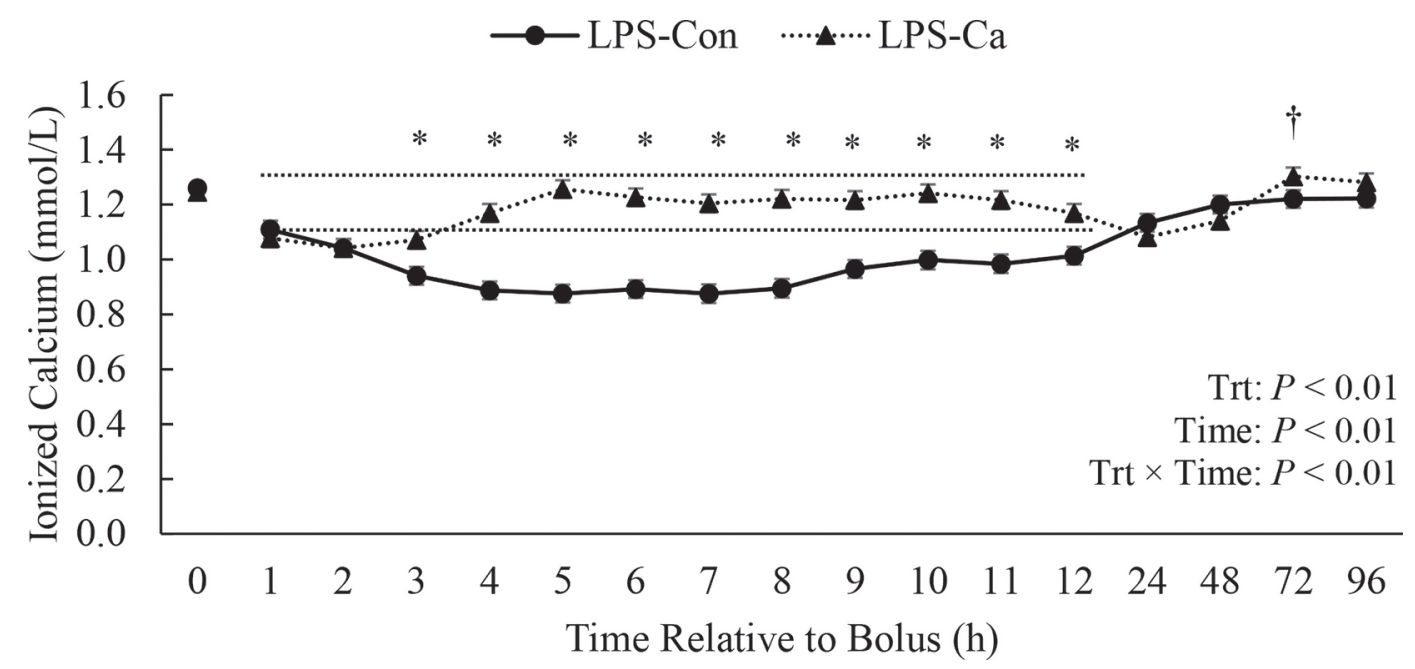

Figure 1. Ionized Ca concentrations from cows allowed to develop hypocalcemia versus cows maintained at eucalcemia following LPS infu-

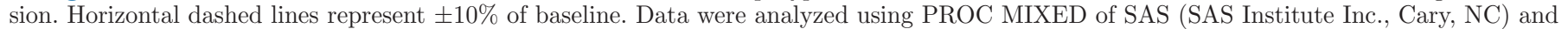

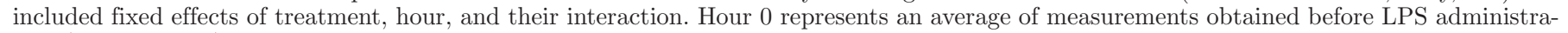

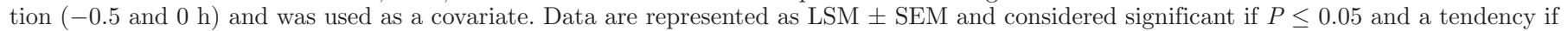

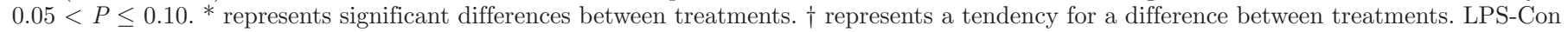
$=$ LPS bolus; LPS-Ca = LPS bolus, Ca infused. 

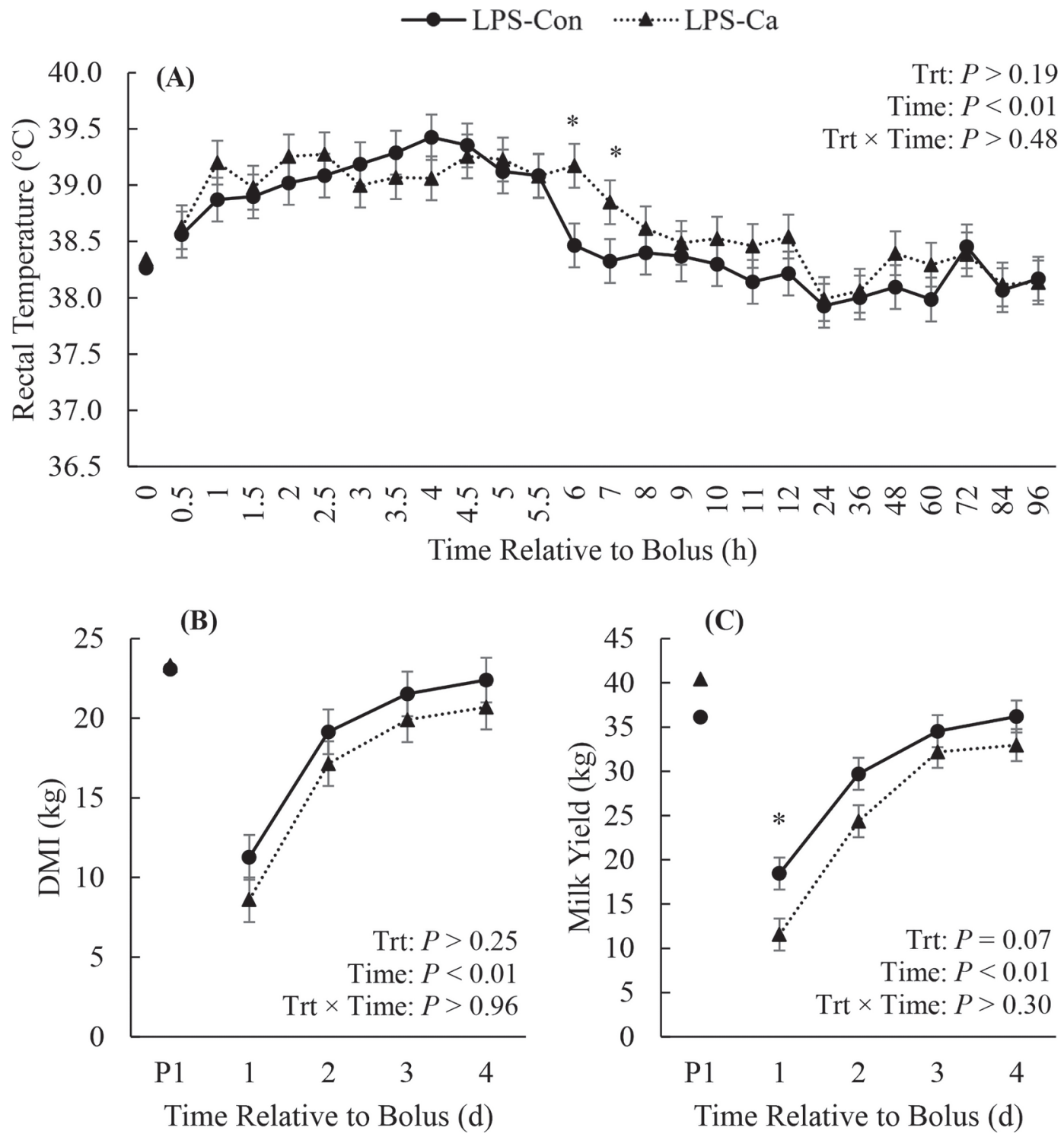

Figure 2. (A) Rectal temperature, (B) DMI, and (C) milk yield from cows allowed to develop hypocalcemia versus cows maintained at eucalcemia following LPS infusion. Data were analyzed using PROC MIXED of SAS (SAS Institute Inc., Cary, NC) and included fixed effects of treatment, time ( $\mathrm{h}$ or $\mathrm{d}$ ), and their interaction. Hour 0 represents an average of measurements obtained before LPS administration ( -0.5 and 0 h) and was used as a covariate for rectal temperature. P1 represents an average of measurements obtained during the $3 \mathrm{~d}$ of period 1 and was used as a covariate for DMI and milk yield. Data are represented as LSM \pm SEM and considered significant if $P \leq 0.05$ and a tendency if 0.05 $<P \leq 0.10{ }^{*}$ represents significant differences between treatments. LPS-Con $=$ LPS bolus; LPS-Ca $=$ LPS bolus, Ca infused.

LPS-Ca cows tended to increase at $6 \mathrm{~h}$ postbolus $(31 \%$; $P=0.07$ ), whereas in LPS-Con cows it remained similar to baseline (Figure 6A). Similarly, MPO exocytosis and total MPO were not influenced by Ca infusion during P2. Neutrophil MPO exocytosis increased (76\%) in both treatments for $12 \mathrm{~h}$ postbolus relative to $\mathrm{P} 1(P$ $\leq 0.10$; Figure 6B). Despite increased exocytosis, total MPO did not differ from P1 in LPS-Con cows; however, it was increased (33\%) $6 \mathrm{~h}$ postbolus in LPS-Ca cows $(P=0.03$; Figure $6 \mathrm{C})$. In agreement with the other neutrophil function metrics, stimulated MPO release did not differ between treatments during P2. However, relative to $\mathrm{P} 1, \mathrm{MPO}$ release increased in both treatments, although the increase was prolonged in LPSCon cows (66\% over the $48 \mathrm{~h} ; P \leq 0.05$; Figure $6 \mathrm{D}$ ).

\section{DISCUSSION}

At lactation onset, dairy cows experience a marked increase in Ca requirements (>65\%; DeGaris and Lean, 2008) to support colostrum and milk synthesis (Horst et al., 2005). Mammary Ca uptake is so acute and ex- 
tensive it often outweighs the homeostatic mechanisms employed to replenish it and consequently clinical hypocalcemia or SCH occurs (Horst et al., 2005; Goff, 2008). Implementing therapeutic and prophylactic strategies has markedly reduced the incidence of clinical hypocalcemia (Charbonneau et al., 2006), but SCH continues to afflict $\sim 25 \%$ of primiparous and $\sim 50 \%$ of multiparous cows in the United States (Reinhardt et al., 2011). Although asymptomatic, SCH has been loosely associated with reduced production performance (i.e., milk yield and feed intake), increased risk of displaced abomasum, immunosuppression (and consequently an increased susceptibility to infectious disease), impaired reproduction, and an overall higher culling risk (Seifi et al., 2011; Oetzel and Miller, 2012; Martinez et al., 2014). Interestingly, the severity of the maladies associated with hypocalcemia appear to be dependent on the magnitude, persistency, and timing of SCH (Caixeta et al., 2017; McArt and Neves, 2020), such that transient hypocalcemia was unrelated to health metrics, whereas persistent and delayed hypocalcemia were associated with detrimental outcomes. These different hypocalcemia "types" may explain why inconsistencies exist regarding the association between hypocalcemia and transition cow health and performance (Martinez et al., 2012; Jawor et al., 2012; Gidd et al., 2015; Venjakob et al., 2018). Although it is becoming evident that not all cases of SCH are equivalent, it remains unclear what underlying factors explain the different hypocalcemia classifications.

Aside from the transition period, we and others have repeatedly demonstrated that experimental immune activation (via LPS infusion) markedly reduces circulating Ca in lactating cows (Griel et al., 1975; Waldron et al., 2003; Kvidera et al., 2017; Horst et al., 2018, 2019; Al-Qaisi et al., 2020) and the response is conserved across species (Tennant et al., 1973; Cardenas-Rivero et al., 1989; Elsasser et al., 1996; Carlstedt et al., 2000; Dias et al., 2013). Immune insults are prevalent in the transition period and it is likely that nearly all cows experience repeated challenges leading up to parturition (Trevisi and Minuti, 2018) and the frequency of these challenges likely relates to the magnitude of inflammation (Trevisi and Minuti, 2018). Interestingly, immune activation was originally hypothesized by early investigators to be involved with milk fever (Thomas, 1889; Hibbs, 1950), but only a few studies in recent literature have considered it to be a contributing factor (Aiumlamai et al., 1992; Eckel and Ametaj, 2016). It is of interest to fully understand the relationship between immune activation and Ca homeostasis and how providing intravenous Ca may alter animal health and productivity as this likely has practical implications to the transition period and farm profitability.

Recently, we demonstrated that oral Ca (in combination with live yeast) before and following LPS administration ameliorates hypocalcemia and improves production performance in lactating cows (Al-Qaisi et al., 2020). However, because the oral bolus contained both $\mathrm{Ca}$ and live yeast we were unable to isolate how each component influenced the response. Yeast has previously been shown to be immunomodulatory (Yuan et al., 2015) and improve production performance (Desnoyers et al., 2009; Zaworski et al., 2014; Broadway et al., 2015); however, some inconsistencies exist (Swartz et al., 1994; Robinson, 1997; Yuan et al., 2015). Given the marked changes in $\mathrm{Ca}$ homeostasis that occur following LPS administration and the role of $\mathrm{Ca}$ in regulating processes such as gastrointestinal motility (Daniel, 1983), metabolism (Martinez et al., 2012, 2014), and immune function (Lewis, 2001; Kimura et al., 2006), we hypothesized that $\mathrm{Ca}$ was the primary mediator of the beneficial effects observed by Al-Qaisi et al. (2020). Thus, study objectives were to evaluate the effects of maintaining eucalcemia following LPS administration on production parameters, inflammatory biomarkers, and PMN function in lactating cows.

In agreement with others (Waldron et al., 2003; Kvidera et al., 2017; Horst et al., 2018; Al-Qaisi et al., 2020), we observed marked and sustained hypocalcemia

Table 2. Milk composition from cows allowed to develop hypocalcemia versus cows maintained at eucalcemia following LPS infusion during period $2(\mathrm{P} 2)^{1}$

\begin{tabular}{|c|c|c|c|c|c|c|}
\hline \multirow[b]{2}{*}{ Item } & \multicolumn{2}{|c|}{ Treatment $^{2}$} & \multirow[b]{2}{*}{ SEM } & \multicolumn{3}{|c|}{$P$-value } \\
\hline & LPS-Con & LPS-Ca & & Treatment & Time & Treatment $\times$ time \\
\hline Fat $(\%)$ & 4.38 & 4.80 & 0.20 & 0.18 & $<0.01$ & 0.12 \\
\hline Lactose (\%) & 4.64 & 4.67 & 0.06 & 0.73 & $<0.01$ & $<0.01$ \\
\hline Protein (\%) & 3.39 & 3.45 & 0.09 & 0.67 & $<0.01$ & 0.06 \\
\hline MUN (mg/dL) & 10.87 & 12.02 & 0.52 & 0.14 & $<0.01$ & 0.45 \\
\hline $\mathrm{SCC}\left(\times 10^{3}\right.$ cells $\left./ \mathrm{mL}\right)$ & 401 & 244 & 91 & 0.24 & 0.53 & 0.58 \\
\hline
\end{tabular}

${ }^{1}$ Data presented as an average value from samples collected during the $4 \mathrm{~d}$ of P2.

${ }^{2}$ LPS-Con $=$ LPS bolus; LPS-Ca $=$ LPS bolus, Ca infused. 


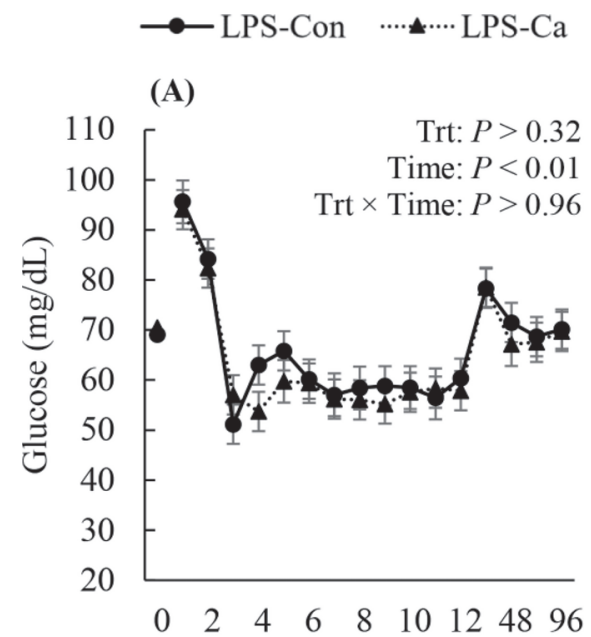

(B)

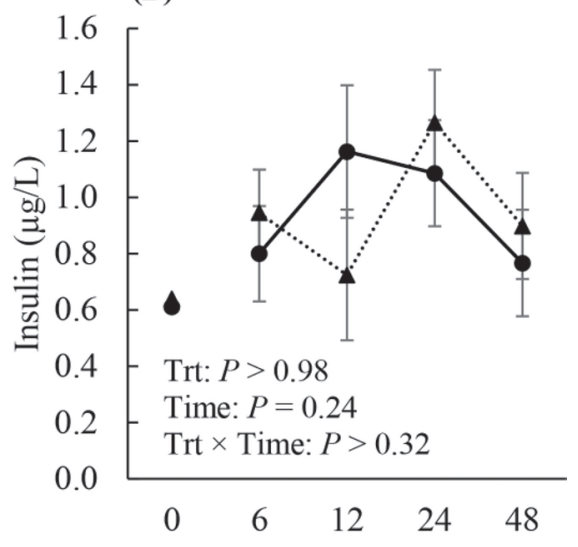

(C)

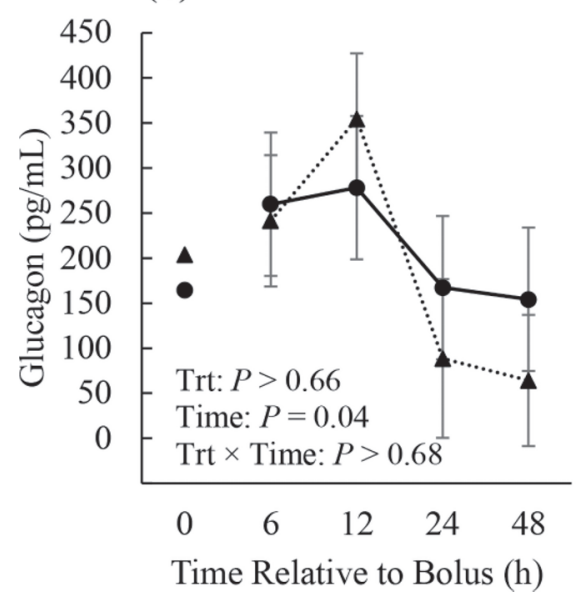

Figure 3. Circulating (A) glucose, (B) insulin, and (C) glucagon from cows allowed to develop hypocalcemia versus cows maintained at eucalcemia following LPS infusion. Data were analyzed using PROC MIXED of SAS (SAS Institute Inc., Cary, NC) and included fixed effects of treatment, hour, and their interaction. Hour 0 represents an average of measurements obtained before LPS administration $(-0.5$ and $0 \mathrm{~h}$ ) and was used as a covariate. Data are represented as LSM \pm SEM and considered significant if $P \leq 0.05$ and a tendency if $0.05<$ $P \leq 0.10$. LPS-Con $=$ LPS bolus; LPS-Ca $=$ LPS bolus, Ca infused (in the LPS-Con cows) in response to LPS administration. Furthermore, we successfully maintained eucalcemia for $12 \mathrm{~h}$ post-LPS administration via continuous intravenous Ca infusion in the LPS-Ca treatment. The decrease in milk yield following LPS infusion allowed us to calculate the amount of $\mathrm{Ca}$ not going toward milk synthesis (milk Ca deficit). The milk $\mathrm{Ca}$ deficit was 10.4 and $6.5 \mathrm{~g}$ for LPS-Con and LPS-Ca cows, respectively. In LPS-Con cows the milk Ca deficit makes up the entirety of the total Ca deficit calculation. In LPS-Ca cows the amount of Ca infused during the 12-h eucalcemic-clamp was $13.7 \mathrm{~g}$, which provides a total Ca deficit of $20.2 \mathrm{~g}$ in LPS-Ca cows. Even though we and others have repeatedly demonstrated LPS-induced hypocalcemia, little is known regarding where the 20.2 $\mathrm{g}$ of $\mathrm{Ca}$ is going and what mechanisms are regulating the disappearance.

Circulating $\mathrm{Ca}$ is normally under tight homeostatic control; however, during inflammation key Ca homeostatic regulators are markedly altered to favor hypocalcemia. For example, although not always consistent (Toribio et al., 2005; Merriman et al., 2018), hypoparathyroidism (Nielsen et al., 1997; Holowaychuk et al., 2012), increased circulating calcitonin and procalcitonin (Müller et al., 2000; Bonelli et al., 2018), and decreased 1,25- $(\mathrm{OH})_{2} \mathrm{D}$ concentrations (Waldron et al., 2003; Holowaychuk et al., 2012) are observed in immunoactivated states. Cytokines released during infection upregulate the parathyroid Ca sensing receptor, reducing the threshold necessary for suppression of parathyroid hormone secretion (Hendy and Canaff, 2016; Klein, 2018), resulting in hypocalcemia concurrently with hypoparathyroidism. Even if hormonal regulation favors hypocalcemia during immune activation, the acute decrease in $\mathrm{Ca}$ is likely too rapid to be explained by these mechanisms (Waldron et al., 2003). Rather it is probably mediated by changes in cellular/ tissue uptake, systemic clearance, or both.

Extracellular Ca uptake by leukocytes is a key initial feature of activation and is necessary for cell proliferation and function (Lewis, 2001; Bréchard and Tschirhart, 2008). Leukocyte stimulation (i.e., interaction with antigen) triggers a signaling cascade resulting in $\mathrm{Ca}$ influx from the endoplasmic reticulum to the cytosol. This increase in cytosolic Ca signals influx from the extracellular space via $\mathrm{Ca}^{2+}$ release-activated $\mathrm{Ca}^{2+}$ channels (Lewis, 2001). Given the large gradient between extra- and intracellular Ca stores (extracellular concentrations 800-fold greater than intracellular; Goff, 1999) and the relatively small number of leukocytes in circulation (Roland et al., 2014) it is unlikely that increased cellular Ca uptake contributes to decreased circulating concentrations (Waldron et al., 2003). Urinary Ca clearance is another probable source of Ca loss; 


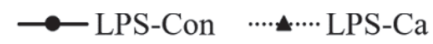

(A)

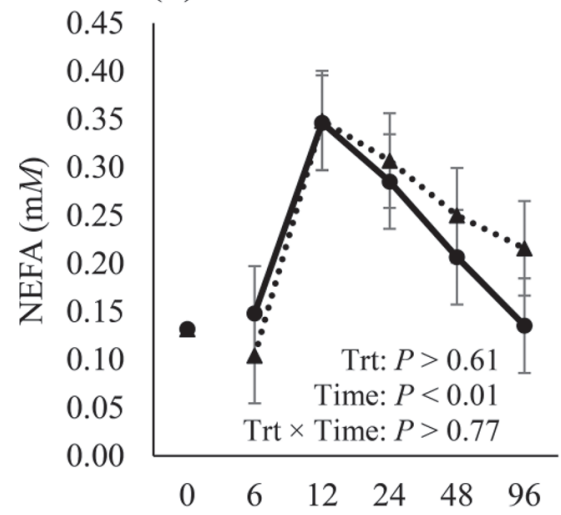

(B)

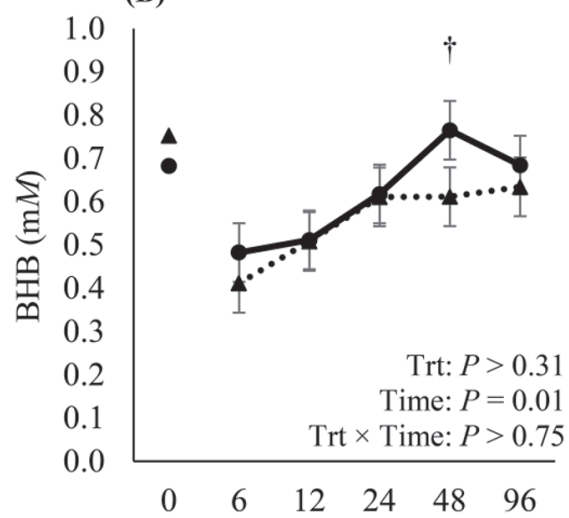

(C)

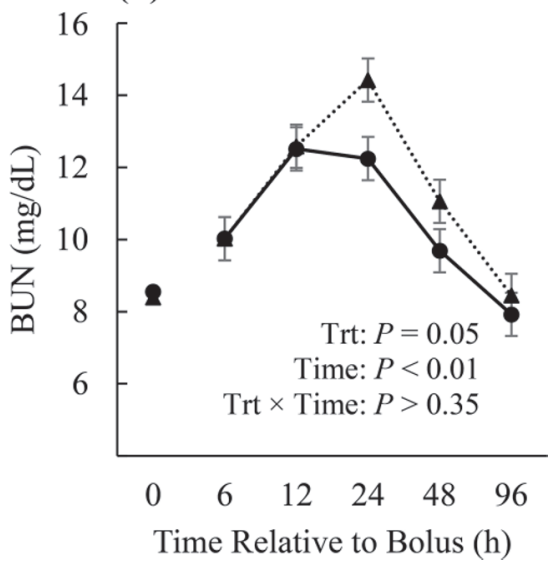

Figure 4. Circulating (A) nonesterified fatty acids (NEFA), (B) $\mathrm{BHB}$, and (C) BUN from cows allowed to develop hypocalcemia versus cows maintained at eucalcemia following LPS infusion. Data were analyzed using PROC MIXED of SAS (SAS Institute Inc., Cary, NC) and included fixed effects of treatment, hour, and their interaction. Hour 0 represents an average of measurements obtained before LPS administration $(-0.5$ and $0 \mathrm{~h})$ and was used as a covariate. Data are represented as LSM \pm SEM and considered significant if $P \leq 0.05$ and a tendency if $0.05<P<0.10$. $\dagger$ represents a tendency for a difference between treatments. LPS-Con $=$ LPS bolus; LPS-Ca $=$ LPS bolus, Ca infused.

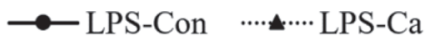

(A)

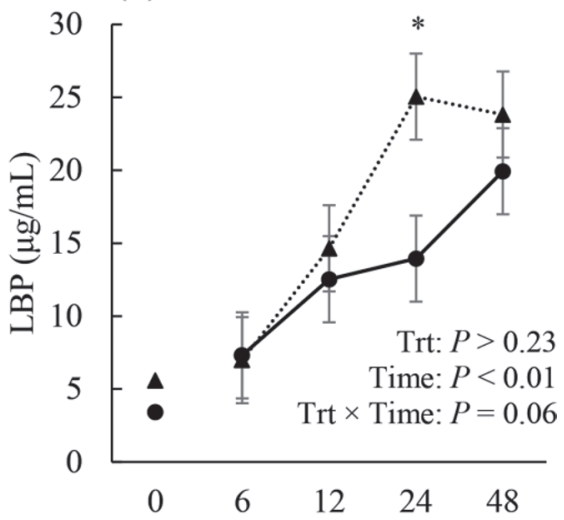

(B)

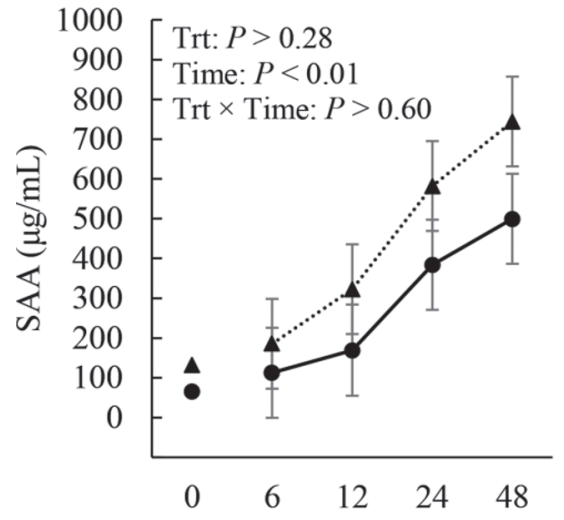

(C)

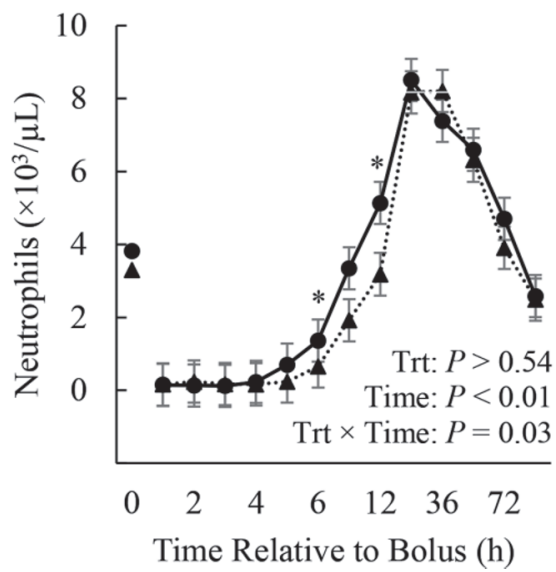

Figure 5. Circulating (A) LPS-binding protein (LBP), (B) serum amyloid A (SAA), and (C) neutrophil counts from cows allowed to develop hypocalcemia versus cows maintained at eucalcemia following LPS infusion. Data were analyzed using PROC MIXED of SAS (SAS Institute Inc., Cary, NC) and included fixed effects of treatment, hour, and their interaction. Hour 0 represents an average of measurements obtained before LPS administration $(-0.5$ and $0 \mathrm{~h})$ and was used as a covariate. Data are represented as LSM \pm SEM and considered significant if $P \leq 0.05$ and a tendency if $0.05<P<0.10{ }^{*}$ represents significant differences between treatments. LPS-Con $=$ LPS bolus; LPS-Ca $=$ LPS bolus, Ca infused. 
however, reports in rodents demonstrated enhanced renal Ca conservation in response to LPS administration (Proksch et al., 1996; Ikeda et al., 2014; Meurer and Höcherl, 2019), and whether the same is true in ruminants remains to be fully elucidated. Interestingly, milk became more Ca concentrated (50\%) following LPS administration and this effect was most pronounced in the LPS-Ca cows; however, the marked milk yield reduction eliminated the mammary gland as a meaningful Ca sink. Interestingly, increased Ca accumulation in ascites and liver has been observed following endotoxin administration in pigs (Carlstedt et al., 2000). Whether Ca sequestration at these sites explains the magnitude of plasma Ca reduction observed and whether it occurs similarly in ruminants is not fully understood and warrants further investigation, especially considering its practical importance to transition cows.

Decreased production performance (i.e., milk yield and DMI) is a typical response during infection and the magnitude of milk yield and DMI reduction observed herein agrees with previous LPS bolus studies (Waldron et al., 2003; Kvidera et al., 2017; Horst et al., 2018). Interestingly, and in contrast to expectations, we observed an exacerbated decrease in milk synthesis and a delayed return to euphagia when eucalcemia was maintained. Pernicious phenotypic responses were surprising considering improved productivity occurred when oral Ca was provided before and following LPS administration (Al-Qaisi et al., 2020). Reasons for the aforementioned discrepancies are unclear, but may be explained by administration route, effects of secondary signals, or the confounding effects of yeast. Intravenous $\mathrm{Ca}$ is apparently detrimental to hormonal regulation of $\mathrm{Ca}$ when compared with oral delivery, and studies suggest it should not be used to treat SCH (Wilms et al., 2019). However, because Ca was purposely infused to avoid hypercalcemia, it is unlikely that signaling pathways controlling $\mathrm{Ca}$ status were meaningfully altered herein. The release of secondary secretagogues in response to oral $\mathrm{Ca}$ is an intriguing explanation for the improved performance observed by Al-Qaisi et al. (2020). For example, Ca-sensing receptors initiate a plethora of signaling pathways regulating appetite, gut motility, metabolism, immune function, and inflammation (Brennan et al., 2014; Rehfeld, 2017; Liu et al., 2018). It remains unclear whether the absence of these secondary mediators with intravenous $\mathrm{Ca}$ can explain the marked differences between our former (Al-Qaisi et al., 2020) and current experiment. Future research investigating the mechanisms of oral versus intravenous $\mathrm{Ca}$ administration following immunoactivation is warranted.

Successful immune activation was induced herein as indicated by changes in leukocyte dynamics and function, mild hyperthermia, and a marked increase in acute phase proteins (APP). In response to LPSadministration we observed a biphasic response in circulating neutrophils with initial neutropenia followed by neutrophilia, which agrees with past reports (Bannerman et al., 2008; Horst et al., 2018). Reduced circulating neutrophil counts likely represent leukocyte endothelial adherence, tissue migration, or increased appearance in the marginated pool (Hoedemaker et al., 1992; Lang et al., 1992; Walther et al., 2000). Interestingly, neutropenia was more pronounced in Ca-infused cows from 9 to $12 \mathrm{~h}$ postbolus compared with LPS-Con cows. Although not entirely clear, this may indicate increased neutrophil extravasation or reduced production from bone marrow. Calcium is well known for its roles in regulating leukocyte function (i.e., migration, endothelial adherence, phagocytosis, and so on; Cohen, 1994; Immler et al., 2018). Although not always consistent (Miltenburg et al., 2018), decreased circulating Ca concentrations have been associated with reduced leukocyte activity in cows (Ducusin et al., 2003; Kimura et al., 2006; Martinez et al., 2012; Zhang et al., 2019) and increasing $\mathrm{Ca}$ concentrations improved leukocyte activity (Vieira-Neto et al., 2017). Surprisingly, despite severe hypocalcemia in response to LPS we observed either no change or actually improved neutrophil function (i.e., MPO activity and oxidative burst). Additionally, Ca infusion had no effect on neutrophil function, which agrees with others (Kehrli and Goff, 1989; Miltenburg et al., 2018). Although our model is acute and is not

Table 3. Circulating leukocytes from cows allowed to develop hypocalcemia versus cows maintained at eucalcemia following LPS infusion during period $2(\mathrm{P} 2)^{1}$

\begin{tabular}{|c|c|c|c|c|c|c|}
\hline Item & \multicolumn{2}{|c|}{ Treatment $^{2}$} & SEM & \multicolumn{3}{|c|}{$P$-value } \\
\hline $\begin{array}{l}\text { White blood cells }\left(\times 10^{3} / \mu \mathrm{L}\right) \\
\text { Monocytes }\left(\times 10^{3} / \mu \mathrm{L}\right) \\
\text { Lymphocytes }\left(\times 10^{3} / \mu \mathrm{L}\right)\end{array}$ & $\begin{array}{l}6.71 \\
0.21 \\
3.11\end{array}$ & $\begin{array}{l}6.49 \\
0.17 \\
2.94\end{array}$ & $\begin{array}{l}0.58 \\
0.05 \\
0.20\end{array}$ & $\begin{array}{l}0.80 \\
0.57 \\
0.55\end{array}$ & $\begin{array}{l}<0.01 \\
<0.01 \\
<0.01\end{array}$ & $\begin{array}{l}0.93 \\
0.73 \\
0.57\end{array}$ \\
\hline
\end{tabular}

${ }^{1}$ Data presented as an average value from samples collected during the $4 \mathrm{~d}$ of P2.

${ }^{2}$ LPS-Con = LPS bolus; LPS-Ca = LPS bolus, Ca infused. 
$\longrightarrow$ LPS-Con $\quad \cdots \cdot \ldots \cdot \cdots$ LPS-Ca

(A)

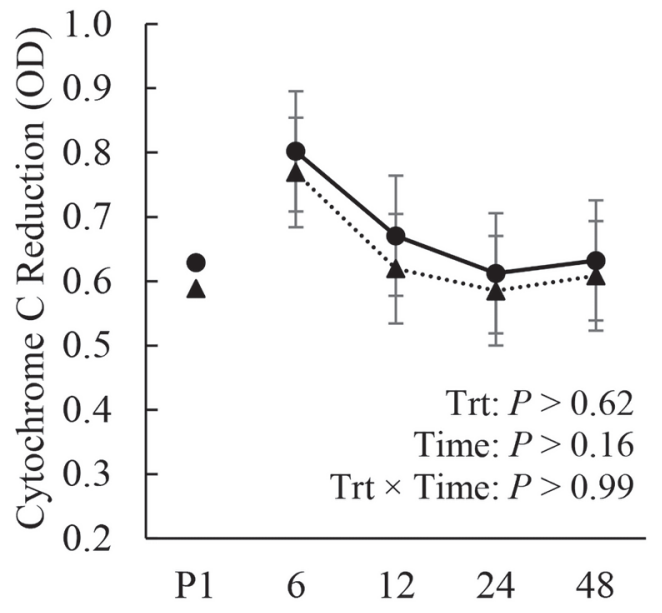

(C)

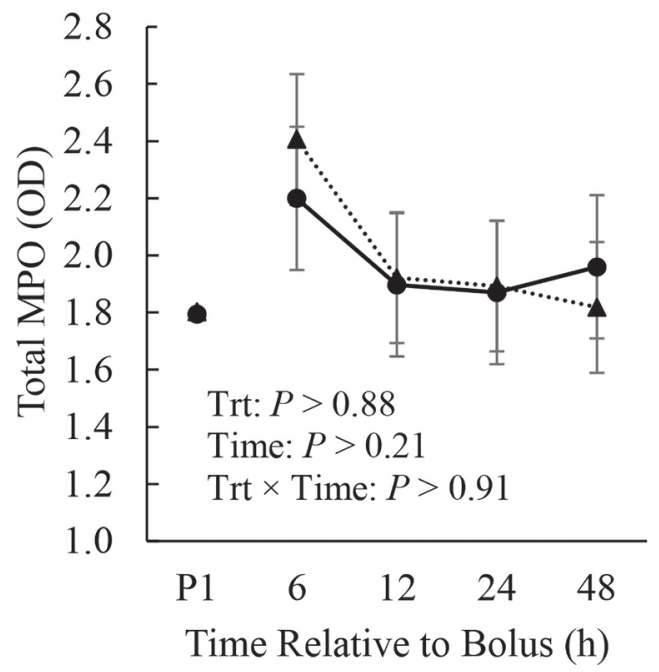

(B)

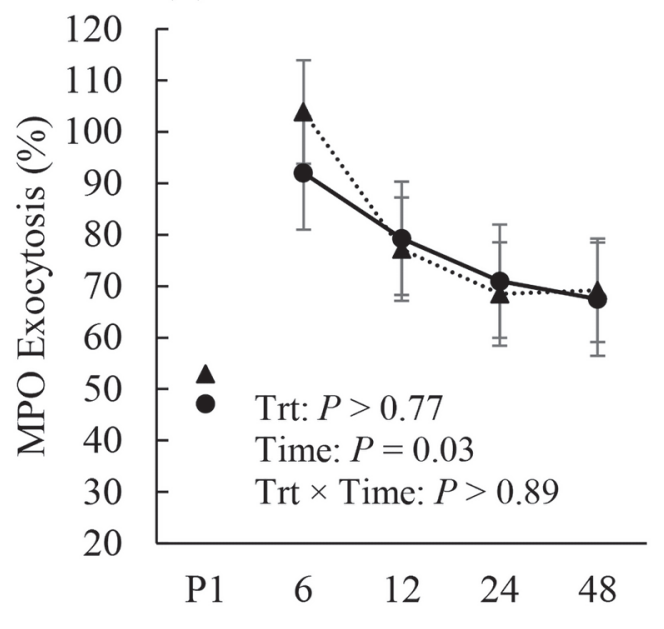

(D)

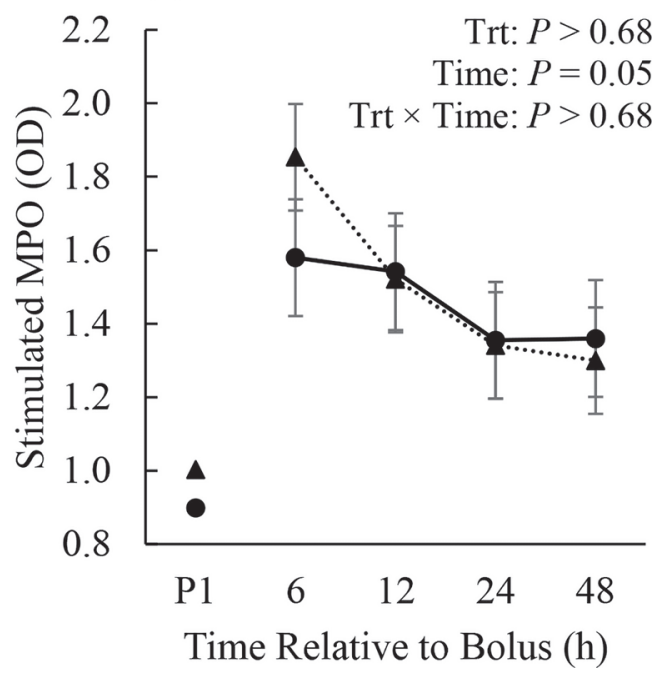

Figure 6. Neutrophil (A) cytochrome C reduction, (B) myeloperoxidase (MPO) exocytosis, (C) total MPO, and (D) stimulated MPO release from cows allowed to develop hypocalcemia versus cows maintained at eucalcemia following LPS infusion. Data were analyzed using PROC MIXED of SAS (SAS Institute Inc., Cary, NC) and included fixed effects of treatment, hour, and their interaction. P1 represents an average of measurements obtained during the $3 \mathrm{~d}$ of $\mathrm{P} 1$ and was used as a covariate. Data are represented as LSM \pm SEM and considered significant if $P$ $\leq 0.05$ and a tendency if $0.05<P \leq 0.10$. LPS-Con = LPS bolus; LPS-Ca $=$ LPS bolus, Ca infused. OD = optical density.

accompanied with periparturient physiological changes, our results challenge the tenet that hypocalcemia is the primary cause of postcalving immunosuppression (Ducusin et al., 2003; Kimura et al., 2006; Martinez et al., 2014). It is likely that the proposed transition cow immunosuppression is multifactorial and cannot be explained by a single factor.

Interestingly, cows maintained at eucalcemia postLPS administration had significantly increased LBP and numerically increased SAA when compared with cows allowed to develop hypocalcemia. This contradicts our previous report in LPS-infused cows (Al-Qaisi et al., 2020) as well as reports in inflamed transition cows (Benzaquen et al., 2015) provided oral Ca. Reasons for observing differences in APP are not entirely clear, but may be explained by the proposed role of $\mathrm{Ca}$ in LPS detoxification and its downstream effects on the inflammatory response (Skarnes and Chedid, 1964). During hypocalcemia, LPS aggregation is inhibited, allowing LBP to transfer LPS monomers to cluster of differentiation 14 and eventually to acute-phase high-density lipoproteins (ap-HDL) and apparently excreted by 
the liver. Formation of ap-HDL is mediated by SAA displacement of apolipoprotein from normal HDL (as reviewed by Eckel and Ametaj, 2016). When eucalcemia is maintained, LPS monomers remain aggregated and this prevents its transfer to lipoproteins (Skarnes and Chedid, 1964). Maintaining extracellular Ca levels increases chemokine and cytokine release by circulating leukocytes, thereby intensifying the inflammatory response (Rossol et al., 2012; Klein et al., 2016). For these reasons, LPS-induced hypocalcemia was opined to serve as a protective strategy during immune activation (Malcolm et al., 1989; Collage et al., 2013; Klein, 2018). This tenet is supported by the fact that Ca administration in septic states increases rates of organ failure and mortality (Malcolm et al., 1989; Hastbacka and Pettila, 2003; Dias et al., 2013). Thus, increased LBP observed herein may represent impaired lipoprotein-mediated LPS detoxification. While Ca infusion may have prevented LPS disaggregation, the numerical increase in SAA concentrations from LPS-Ca cows may suggest formation of the ap-HDL molecule was not disrupted. Whether the changes in APP we observed with Ca infusion reflect an improved capacity to clear infection via pro-inflammatory mechanisms or an overly exaggerated immune response remain unclear, but the production responses (i.e., decreased milk yield and delayed return to baseline DMI) and heightened febrile response suggest the latter. The reasons why oral Ca administration in LPS-administered cows did not alter APP production are unclear, but may be explained by the quantity of $\mathrm{Ca}$ appearing in circulation and the rate at which it entered. Further investigation into the role of $\mathrm{Ca}$ in inflammation and how ameliorating hypocalcemia may influence animal health and wellbeing is of obvious interest.

The energetic requirements of immunoactivation are substantial and supporting the response requires marked alterations in nutrient partitioning (Johnson, 2012; Kvidera et al., 2017; Horst et al., 2018). The metabolic and hormonal changes implemented in response to LPS have been detailed in many of our recent publications (Kvidera et al., 2017; Horst et al., 2018, 2019). In agreement with our previous work, LPS administration increased circulating insulin, glucagon, and NEFA, but the patterns did not differ when eucalcemia was maintained. Not observing differences in circulating insulin was surprising considering the role of $\mathrm{Ca}$ in insulin secretion from pancreatic $\beta$ cells (Rorsman and Trube, 1986). Additionally, others have previously demonstrated hypoinsulinemia when administrating the Ca chelator ethylene glycol tetraacetic acid in cows (Martinez et al., 2014). Interestingly, we observed increased circulating BUN in LPS-Ca cows, which agrees with changes in MUN, and as aforementioned may be con- nected to the changes observed in circulating APP as skeletal muscle proteolysis is an important source of AA needed for APP synthesis (Johnson, 2012). Circulating $\mathrm{BHB}$ was decreased with $\mathrm{Ca}$ administration; however, the biological significance of this decrease is unclear. The mechanisms driving decreased BHB concentrations during infection remain largely unexplained; however, increased peripheral utilization (Zarrin et al., 2014; E. A. Horst and L. H. Baumgard, unpublished data) and reduced production from the rumen epithelium (Pennington, 1952) due to decreased substrate are possible contributors. Interestingly, the return to baseline BHB concentrations occurred before the return of euphagia, which suggests reduced rumen epithelial production is not the primary reason for decreased circulating ketones.

\section{CONCLUSIONS}

Our results validate LPS administration as an effective model for inducing hypocalcemia. In contrast to oral Ca supplementation, we have demonstrated potential negative consequences (i.e., decreased milk yield and slower return to baseline DMI) of intravenous Ca infusion during immunoactivation and demonstrated little to no benefit of maintaining eucalcemia on leukocyte function. Additionally, Ca infusion increased circulating LBP concentrations, which may suggest an impaired capacity to detoxify LPS via noninflammatory routes. Future work should focus on the direct effect of Ca on lipoprotein-mediated LPS detoxification and how it may affect an inflammatory response.

\section{ACKNOWLEDGMENTS}

Research funding was provided by the Norman Jacobson Endowment (Iowa State University, Ames). The authors have not stated any conflicts of interest.

\section{REFERENCES}

Abuajamieh, M., S. K. Kvidera, M. V. Fernandez, A. Nayeri, N. C. Upah, E. A. Nolan, S. M. Lei, J. M. DeFrain, H. B. Green, K. M. Schoenberg, W. E. Trout, and L. H. Baumgard. 2016. Inflammatory biomarkers are associated with ketosis in periparturient Holstein cows. Res. Vet. Sci. 109:81-85. https://doi.org/10.1016/ j.rvsc.2016.09.015.

Aiumlamai, S., G. Fredriksson, H. Kindahl, and L. E. Edqvist. 1992. A possible role of endotoxins in spontaneous paretic cows around parturition. Zentralbl. Veterinarmed. A 39:57-68. https://doi.org/ 10.1111/j.1439-0442.1992.tb00156.x.

Al-Qaisi, M., S. K. Kvidera, E. A. Horst, C. S. McCarthy, E. J. Mayorga, M. A. Abeyta, B. M. Goetz, N. C. Upah, D. M. McKilligan, H. A. Ramirez-Ramirez, L. L. Timms, and L. H. Baumgard. 2020. Effects of an oral supplement containing calcium and live yeast on post-absorptive metabolism, inflammation and production following intravenous lipopolysaccharide infusion in dairy cows. Res. Vet. Sci. 129:74-81. https://doi.org/10.1016/j.rvsc.2020.01.007. 
Ametaj, B. N., B. J. Bradford, G. Bobe, R. A. Nafikov, Y. Lu, J. W. Young, and D. C. Beitz. 2005. Strong relationships between mediators of the acute phase response and fatty liver in dairy cows. Can. J. Anim. Sci. 85:165-175. https://doi.org/10.4141/A04-043.

Ametaj, B. N., Q. Zebeli, and S. Iqbal. 2010. Nutrition, microbiota, and endotoxin-related diseases in dairy cows. Rev. Bras. Zootec. 39(suppl spe):433-444. https://doi.org/10.1590/S1516 -35982010001300048 .

AOAC International. 1995. AOAC official method 972.16. Fat, lactose, protein, and solids in milk. Mid infrared spectroscopic method. Pages 23-26 in Official Methods of Analysis. 16th ed. Vol. 2. AOAC International, Arlington, VA.

Bannerman, D. D., A. C. W. Kauf, M. J. Paape, H. R. Springer, and J. P. Goff. 2008. Comparison of Holstein and Jersey innate immune responses to Escherichia coli intramammary infection. J. Dairy Sci. 91:2225-2235. https://doi.org/10.3168/jds.2008-1013.

Benzaquen, M., K. N. Galvão, A. E. Coleman, J. E. P. Santos, J. P. Goff, and C. A. Risco. 2015. Effect of oral mineral and energy supplementation on blood mineral concentrations, energetic and inflammatory profile, and milk yield in dairy cows affected with dystocia. Vet. J. 204:186-191. https://doi.org/10.1016/j.tvjl.2015 .03 .001 .

Bertoni, G., E. Trevisi, X. Han, and M. Bionaz. 2008. Effects of inflammatory conditions on liver activity in puerperium period and consequences for performance in dairy cows. J. Dairy Sci. 91:33003310. https://doi.org/10.3168/jds.2008-0995.

Bonelli, F., V. Meucci, T. J. Divers, A. Boccardo, D. Pravettoni, M. Meylan, A. G. Belloli, and M. Sgorbini. 2018. Plasma procalcitonin concentration in healthy calves and those with septic systemic inflammatory response syndrome. Vet. J. 234:61-65. https://doi .org/10.1016/j.tvjl.2018.02.003.

Bradford, B. J., K. Yuan, J. K. Farney, L. K. Mamedova, and A. J. Carpenter. 2015. Invited review: Inflammation during the transition to lactation: New adventures with an old flame. J. Dairy Sci. 98:6631-6650. https://doi.org/10.3168/jds.2015-9683.

Bréchard, S., and E. J. Tschirhart. 2008. Regulation of superoxide production in neutrophils: Role of calcium influx. J. Leukoc. Biol. 84:1223-1237. https://doi.org/10.1189/jlb.0807553.

Brennan, S. C., T. S. Davies, M. Schepelmann, and D. Riccardi. 2014. Emerging roles of the extracellular calcium-sensing receptor in nutrient sensing: Control of taste modulation and intestinal hormone secretion. Br. J. Nutr. 111(S1):S16-S22. https://doi.org/10.1017/ S0007114513002250.

Broadway, P. R., J. A. Carroll, and N. C. Sanchez. 2015. Live yeast and yeast cell wall supplements enhance immune function and performance in food-producing livestock: a review. Microorganisms 3:417-427. https://doi.org/10.3390/microorganisms3030417.

Caixeta, L. S., P. A. Ospina, M. B. Capel, and D. V. Nydam. 2017. Association between subclinical hypocalcemia in the first 3 days of lactation and reproductive performance of dairy cows. Theriogenology 94:1-7. https://doi.org/10.1016/j.theriogenology.2017.01 .039 .

Cardenas-Rivero, N., B. Chernow, M. A. Stoiko, S. R. Nussbaum, and I. D. Todres. 1989. Hypocalcemia in critically ill children. J. Pediatr. 114:946-951. https://doi.org/10.1016/S0022-3476(89)80435-4.

Carlstedt, F., M. Eriksson, R. Kiiski, A. Larsson, and L. Lind. 2000. Hypocalcemia during porcine endotoxemic shock: Effects of calcium administration. Crit. Care Med. 28:2909-2914. https://doi .org/10.1097/00003246-200008000-00037.

Chapinal, N., M. Carson, T. F. Duffield, M. Capel, S. Godden, M. Overton, J. E. P. Santos, and S. J. LeBlanc. 2011. The association of serum metabolites with clinical disease during the transition period. J. Dairy Sci. 94:4897-4903. https://doi.org/10.3168/jds $.2010-4075$.

Charbonneau, E., D. Pellerin, and G. R. Oetzel. 2006. Impact of lowering dietary cation-anion difference in nonlactating dairy cows: A meta-analysis. J. Dairy Sci. 89:537-548. https://doi.org/10.3168/ jds.S0022-0302(06)72116-6.

Cohen, M. S. 1994. Molecular events in the activation of human neutrophils for microbial killing. Clin. Infect. Dis.
18(Supplement_2):S170-S179. https://doi.org/10.1093/clinids/18 .Supplement_2.S170.

Collage, R. D., G. M. Howell, X. Zhang, J. L. Stripay, J. S. Lee, D. C. Angus, and M. R. Rosengart. 2013. Calcium supplementation during sepsis exacerbates organ failure and mortality via calcium/ calmodulin-dependent protein kinase kinase (CaMKK) signaling. Crit. Care Med. 41:e352-e360. https://doi.org/10.1097/CCM $.0 \mathrm{~b} 013 \mathrm{e} 31828 \mathrm{cf} 436$.

Daniel, R. C. 1983. Motility of the rumen and abomasum during hypocalcemia. Can. J. Comp. Med. 47:276-280.

DeGaris, P. J., and I. J. Lean. 2008. Milk fever in dairy cows: A review of pathophysiology and control principles. Vet. J. 176:58-69. https: //doi.org/10.1016/j.tvjl.2007.12.029.

Desnoyers, M., S. Giger-Reverdin, G. Bertin, C. Duvaux-Ponter, and D. Sauvant. 2009. Meta-analysis of the influence of Saccharomyces cerevisiae supplementation on ruminal parameters and milk production of ruminants. J. Dairy Sci. 92:1620-1632. https://doi.org/ 10.3168/jds.2008-1414.

Dias, C. R., H. P. Leite, P. C. Nogueira, and W. B. de Carvalho. 2013. Ionized hypocalcemia is an early event and is associated with organ dysfunction in children admitted to the intensive care unit. J. Crit. Care 28:810-815. https://doi.org/10.1016/j.jcrc.2013.03.019.

Domino, A. R., H. C. Korzec, and J. A. A. McArt. 2017. Field trial of 2 calcium supplements on early lactation health and production in multiparous Holstein cows. J. Dairy Sci. 100:9681-9690. https:// doi.org/10.3168/jds.2017-12885.

Ducusin, R. J. T., Y. Uzuka, E. Satoh, M. Otani, M. Nishimura, S. Tanabe, and T. Sarashina. 2003. Effects of extracellular $\mathrm{Ca}^{2+}$ on phagocytosis and intracellular $\mathrm{Ca}^{2+}$ concentrations in polymorphonuclear leukocytes of postpartum dairy cows. Res. Vet. Sci. 75:27-32. https://doi.org/10.1016/S0034-5288(03)00038-9.

Eckel, E. F., and B. N. Ametaj. 2016. Invited Review: Role of bacterial endotoxins in the etiopathogenesis of periparturient diseases of transition dairy cows. J. Dairy Sci. 99:5967-5990. https://doi.org/ 10.3168/jds.2015-10727.

Elsasser, T. H., M. Richards, R. Collier, and G. F. Hartnell. 1996. Physiological responses to repeated endotoxin challenge are selectively affected by recombinant bovine somatotropin administration to calves. Domest. Anim. Endocrinol. 13:91-103. https://doi .org/10.1016/0739-7240(95)00048-8.

Gidd, C., N. Alpert, and M. van Straten. 2015. The influence of SCH on milk production and reproduction in Israeli dairy hers. Isr. J. Vet. Med. 70:16-21.

Goff, J. P. 1999. Treatment of calcium, phosphorus, and magnesium balance disorders. Vet. Clin. North Am. Food Anim. Pract. 15:619-639. https://doi.org/10.1016/S0749-0720(15)30167-5.

Goff, J. P. 2008. The monitoring, prevention, and treatment of milk fever and subclinical hypocalcemia in dairy cows. Vet. J. 176:50-57. https://doi.org/10.1016/j.tvjl.2007.12.020.

Griel, L. C., A. Zarkower, and R. J. Eberhart. 1975. Clinical and clinico-pathological effects of Escherichia coli endotoxin in mature cattle. Can. J. Comp. Med. 39:1-6.

Hastbacka, J., and V. Pettila. 2003. Prevalence and predictive value of ionized hypocalcemia among critically ill patients. Acta Anaesthesiol. Scand. 47:1264-1269. https://doi.org/10.1046/j.1399-6576 .2003.00236.x.

Hendy, G. N., and L. Canaff. 2016. Calcium-sensing receptor, proinflammatory cytokines and calcium homeostasis. Semin. Cell Dev. Biol. 49:37-43. https://doi.org/10.1016/j.semcdb.2015.11.006.

Hibbs, J. W. 1950. Milk fever (parturient paresis) in dairy cows-A review. J. Dairy Sci. 33:758-789. https://doi.org/10.3168/jds.S0022 -0302(50)91966-7.

Hoedemaker, M., L. A. Lund, and W. C. Wagner. 1992. Function of neutrophils and chemoattractant properties of fetal placental tissue during the last month of pregnancy in cows. Am. J. Vet. Res. 53:1524-1529.

Holowaychuk, M. K., A. J. Birkenheuer, J. Li, H. Marr, A. Boll, and S. K. Nordone. 2012. Hypocalcemia and hypovitaminosis D in dogs with induced endotoxemia. J. Vet. Intern. Med. 26:244-251. https: //doi.org/10.1111/j.1939-1676.2012.00886.x. 
Horst, E. A., S. K. Kvidera, E. J. Mayorga, C. S. Shouse, M. Al-Qaisi, M. J. Dickson, J. Ydstie, H. A. Ramirez Ramirez, A. F. Keating, D. J. Dickson, K. E. Griswold, and L. H. Baumgard. 2018. Effect of chromium on bioenergetics and leukocyte dynamics following immunoactivation in lactating Holstein cows. J. Dairy Sci. 101:5515-5530. https://doi.org/10.3168/jds.2017-13899.

Horst, E. A., E. J. Mayorga, M. Al-Qaisi, M. A. Abeyta, B. M. Goetz, H. A. Ramirez Ramirez, D. H. Kleinschmit, and L. H. Baumgard. 2019. Effects of dietary zinc source on the metabolic and immunological response to lipopolysaccharide in lactating Holstein dairy cows. J. Dairy Sci. 102:11681-11700. https://doi.org/10.3168/jds .2019-17037.

Horst, R. L., J. P. Goff, and T. A. Reinhardt. 2005. Adapting to the transition between gestation and lactation: Differences between rat, human and dairy cow. J. Mammary Gland Biol. Neoplasia 10:141-156. https://doi.org/10.1007/s10911-005-5397-x.

Humblet, M. F., H. Guyot, B. Boudry, F. Mbayahi, C. Hanzen, F. Rollin, and J. M. Godeau. 2006. Relationship between haptoglobin, serum amyloid A, and clinical status in a survey of dairy herds during a 6-month period. Vet. Clin. Pathol. 35:188-193. https:// doi.org/10.1111/j.1939-165X.2006.tb00112.x.

Ikeda, S., H. Yamamoto, M. Masuda, Y. Takei, O. Nakahashi, M. Kozai, S. Tanaka, M. Nakao, Y. Taketani, H. Segawa, M. Iwano, K. Miyamoto, and E. Takeda. 2014. Downregulation of renal type IIa sodium-dependent phosphate cotransporter during lipopolysaccharide-induced acute inflammation. Am. J. Physiol. Renal Physiol. 306:F744-F750. https://doi.org/10.1152/ajprenal.00474.2013.

Immler, R., S. I. Simon, and M. Sperandio. 2018. Calcium signaling and related ion channels in neutrophil recruitment and function. Eur. J. Clin. Invest. 48:e12964. https://doi.org/10.1111/eci.12964.

Jawor, P. E., J. M. Huzzey, S. J. LeBlanc, and M. A. von Keyserlingk. 2012. Associations of subclinical hypocalcemia at calving with milk yield, and feeding, drinking, and standing behaviors around parturition in Holstein cows. J. Dairy Sci. 95:1240-1248. https:// doi.org/10.3168/jds.2011-4586.

Johnson, R. W. 2012. Fueling the immune response: What's the cost? Pages 211-223 in Feed Efficiency in Swine. John Patience, Ed. Wageningen Academic Publishers, Wageningen, the Netherlands.

Kehrli, M. E. Jr., and J. P. Goff. 1989. Periparturient hypocalcemia in cows: Effects on peripheral blood neutrophil and lymphocyte function. J. Dairy Sci. 72:1188-1196. https://doi.org/10.3168/jds .S0022-0302(89)79223-7.

Kimura, K., J. P. Goff, P. Canning, C. Wang, and J. A. Roth. 2014. Effect of recombinant bovine granulocyte colony-stimulating factor covalently bound to polyethylene glycol injection on neutrophil number and function in periparturient dairy cows. J. Dairy Sci. 97:4842-4851. https://doi.org/10.3168/jds.2013-7242.

Kimura, K., T. A. Reinhardt, and J. P. Goff. 2006. Parturition and hypocalcemia blunts calcium signals in immune cells of dairy cattle. J. Dairy Sci. 89:2588-2595. https://doi.org/10.3168/jds.S0022 $-0302(06) 72335-9$.

Klein, G. L. 2018. The role of calcium in inflammation-associated bone resorption. Biomolecules 8:69. https://doi.org/10.3390/ biom8030069.

Klein, G. L., S. M. Castro, and R. P. Garofalo. 2016. The calciumsensing receptor as a mediator of inflammation. Semin. Cell Dev. Biol. 49:52-56. https://doi.org/10.1016/j.semcdb.2015.08.006.

Kvidera, S. K., E. A. Horst, M. Abuajamieh, E. J. Mayorga, M. V. Sanz Fernandez, and L. H. Baumgard. 2017. Glucose requirements of an activated immune system in lactating Holstein cows. J. Dairy Sci. 100:2360-2374. https://doi.org/10.3168/jds.2016-12001.

Lang, C. H., G. J. Bagby, C. Dobrescu, A. Ottlakan, and J. J. Spitzer. 1992. Sepsis- and endotoxin-induced increase in organ glucose uptake in leukocyte-depleted rats. Am. J. Physiol. 263:R1324-R1332. https://doi.org/10.1152/ajpregu.1992.263.6.R1324.

Lewis, R. S. 2001. Calcium signaling mechanisms in T lymphocytes. Annu. Rev. Immunol. 19:497-521. https://doi.org/10.1146/ annurev.immunol.19.1.497.

Liu, G., W. Cao, G. Jia, H. Zhao, X. Chen, and J. Wang. 2018. Calcium-sensing receptor in nutrient sensing: an insight into the modu- lation of intestinal homeostasis. Br. J. Nutr. 120:881-890. https:// doi.org/10.1017/S0007114518002088.

Malcolm, D. S., G. P. Zaloga, and J. W. Holaday. 1989. Calcium administration increases the mortality of endotoxic shock in rats. Crit. Care Med. 17:900-903. https://doi.org/10.1097/00003246 $-198909000-00012$.

Martinez, N., C. A. Risco, F. S. Lima, R. S. Bisinotto, L. F. Greco, E. S. Ribeiro, F. Maunsell, K. Galvão, and J. E. P. Santos. 2012. Evaluation of peripartal calcium status, energetic profile, and neutrophil function in dairy cows at low or high risk of developing uterine disease. J. Dairy Sci. 95:7158-7172. https://doi.org/10 $.3168 /$ jds.2012-5812.

Martinez, N., L. D. P. Sinedino, R. S. Bisinotto, E. S. Ribeiro, G. C. Gomes, F. S. Lima, L. F. Greco, C. A. Risco, K. N. Galavão, D. Taylor-Rodriguez, J. P. Driver, W. W. Thatcher, and J. E. P. Santos. 2014. Effect of induced subclinical hypocalcemia on physiological responses and neutrophil function in dairy cows. J. Dairy Sci. 97:874-887. https://doi.org/10.3168/jds.2013-7408.

McArt, J. A. A., and R. C. Neves. 2020. Association of transient, persistent, or delayed subclinical hypocalcemia with early lactation disease, removal, and milk yield in Holstein cows. J. Dairy Sci. 103:690-701. https://doi.org/10.3168/jds.2019-17191.

Merriman, K. E., J. L. Powell, J. E. P. Santos, and C. D. Nelson. 2018. Intramammary 25-hydroxyvitamin $\mathrm{D}_{3}$ treatment modulates innate immune responses to endotoxin-induced mastitis. J. Dairy Sci. 101:7593-7607.

Meurer, M., and K. Höcherl. 2019. Endotoxaemia differentially regulates the expression of renal $\mathrm{Ca}^{2+}$ transport proteins in mice. Acta Physiol. (Oxf.) 225:e13175. https://doi.org/10.1111/apha.13175.

Miltenburg, C. L., T. F. Duffield, D. Bienzle, E. L. Scholtz, and S. J. LeBlanc. 2018. Short communication: The effect of calcium supplementation at calving on neutrophil function. J. Dairy Sci. 101:9505-9509. https://doi.org/10.3168/jds.2018-14839.

Müller, B., K. L. Becker, M. Kränzlin, H. Schachinger, P. R. Huber, E. S. Nylén, R. H. Snider, J. C. White, H. Schmidt-Gayk, W. Zimmerli, and R. Ritz. 2000. Disordered calcium homeostasis of sepsis: Association with calcitonin precursors. Eur. J. Clin. Invest. 30:823-831. https://doi.org/10.1046/j.1365-2362.2000.00714.x.

NRC. 2001. Nutrient Requirements of Dairy Cattle. 7th rev. ed. Natl. Acad. Press, Washington, DC.

Naylor, J. M., and D. S. Kronfeld. 1986. Relationships between metabolic changes and clinical signs in pregnant sheep given endotoxin. Can. J. Vet. Res. 50:402-409.

Nielsen, P. K., A. K. Rasmussen, R. Butters, U. Feldt-Rasmussen, K. Bendtzen, R. Diaz, E. M. Brown, and K. Olgaard. 1997. Inhibition of PTH secretion by interleukin-1 $\beta$ in bovine parathyroid glands in vitro is associated with an upregulation of the calcium-sensing receptor mRNA. Biochem. Biophys. Res. Commun. 238:880-885. https://doi.org/10.1006/bbrc.1997.7207.

Oetzel, G. R. 1996. Effect of calcium chloride gel treatment in dairy cows on incidence of periparturient diseases. J. Am. Vet. Med. Assoc. 209:958-961.

Oetzel, G. R. 2013. Oral calcium supplementation in peripartum dairy cows. Vet. Clin. North Am. Food Anim. Pract. 29:447-455. https: //doi.org/10.1016/j.cvfa.2013.03.006.

Oetzel, G. R., and B. E. Miller. 2012. Effect of oral calcium bolus supplementation on early-lactation health and milk yield in commercial dairy herds. J. Dairy Sci. 95:7051-7065. https://doi.org/ $10.3168 / j d s .2012-5510$

Ohtsuka, H., M. Koiwa, A. Hatsugaya, K. Kudo, F. Hoshi, N. Itoh, H. Yokota, H. Okada, and S. Kawamura. 2001. Relationship between serum TNF activity and insulin resistance in dairy cows affected with naturally occurring fatty liver. J. Vet. Med. Sci. 63:10211025. https://doi.org/10.1292/jvms.63.1021.

Pennington, R. J. 1952. The metabolism of short-chain fatty acids in the sheep. I. Fatty acid utilization and ketone body production by rumen epithelium and other tissues. Biochem. J. 51:251-258. https://doi.org/10.1042/bj0510251.

Proksch, J. W., L. A. Traylor, and P. R. Mayeux. 1996. Effects of Lipid A on calcium homeostasis in renal proximal tubules. J. Pharmacol. Exp. Ther. 276:555-560. 
Rehfeld, J. F. 2017. Cholecystokinin - from local gut hormone to ubiquitous messenger. Front. Endocrinol. (Lausanne) 8:47. https://doi .org/10.3389/fendo.2017.00047.

Reinhardt, T. A., J. D. Lippolis, B. J. McCluskey, J. P. Goff, and R. L. Horst. 2011. Prevalence of subclinical hypocalcemia in dairy herds. Vet. J. 188:122-124. https://doi.org/10.1016/j.tvjl.2010.03.025.

Robinson, P. H. 1997. Effect of yeast culture (Saccharomyces cerevisiae) on adaptation of cows to diets postpartum. J. Dairy Sci. 80:1119-1125. https://doi.org/10.3168/jds.S0022-0302(97)76038 -7 .

Roland, L., M. Drillich, and M. Iwersen. 2014. Hematology as a diagnostic tool in bovine medicine. J. Vet. Diagn. Invest. 26:592-598. https://doi.org/10.1177/1040638714546490.

Rorsman, P., and G. Trube. 1986. Calcium and delayed potassium currents in mouse pancreatic beta-cells under voltage-clamp conditions. J. Physiol. 374:531-550. https://doi.org/10.1113/jphysiol .1986.sp016096.

Rossol, M., M. Pierer, N. Raulien, D. Quandt, U. Meusch, K. Rothe, K. Schubert, T. Schöneberg, M. Schaefer, U. Krügel, S. Smajilovic, H. Bräuner-Osborne, C. Baerwald, and U. Wagner. 2012. Extracellular $\mathrm{Ca} 2+$ is a danger signal activating the NLRP3 inflammasome through $\mathrm{G}$ protein-coupled calcium sensing receptors. Nat. Commun. 3:1329. https://doi.org/10.1038/ncomms2339.

Seifi, H. A., S. J. LeBlanc, K. E. Leslie, and T. F. Duffield. 2011. Metabolic predictors of post-partum disease and culling risk in dairy cattle. Vet. J. 188:216-220. https://doi.org/10.1016/j.tvjl 2010.04.007.

Skarnes, R. C., and L. C. Chedid. 1964. Biological degraduation and inactivation of endotoxin (chromate-labeled). Pages 575-587 in Bacterial Endotoxins. M. Landy and W. Braun, ed. Rutgers University Press, New Brunswick, NJ.

Swartz, D. L., L. D. Muller, G. W. Rogers, and G. A. Varga. 1994. Effect of yeast culture on performance of lactating dairy cows: A field study. J. Dairy Sci. 77:3073-3080. https://doi.org/10.3168/ jds.S0022-0302(94)77249-0.

Tennant, B., M. Reina-Guerra, and D. Harrold. 1973. Metabolic response of calves following acute experimental endotoxemia. Ann. Rech. Vet. 4:135-147.

Thomas, A. H. 1889. Parturient apoplexy in cows-A form of septicaemia. Vet. J. Ann. Comp. Pathol. 28:1-4. https://doi.org/10.1016/ S2543-3377(17)37660-4.

Toribio, R. E., C. W. Kohn, J. Hardy, and T. J. Rosol. 2005. Alterations in serum parathyroid hormone and electrolyte concentrations and urinary excretion of electrolytes in horses with induced endotoxemia. J. Vet. Intern. Med. 19:223-231. https://doi.org/10 $.1111 /$ j.1939-1676.2005.tb02686.x.
Trevisi, E., and A. Minuti. 2018. Assessment of the innate immune response in the periparturient cow. Res. Vet. Sci. 116:47-54. https: //doi.org/10.1016/j.rvsc.2017.12.001.

Venjakob, P. L., L. Pieper, W. Heuwieser, and S. Borchardt. 2018. Association of postpartum hypocalcemia with early-lactation milk yield, reproductive performance, and culling in dairy cows. J. Dairy Sci. 101:9396-9405. https://doi.org/10.3168/jds.2017-14202.

Vieira-Neto, A., I. R. P. Lima, F. Lopes Jr., C. Lopera, R. Zimpel, L. D. P. Sinedino, K. C. Jeong, K. Galvão, W. W. Thatcher, C. D. Nelson, and J. E. P. Santos. 2017. Use of calcitriol to maintain postpartum blood calcium and improve immune function in dairy cows. J. Dairy Sci. 100:5805-5823. https://doi.org/10.3168/ jds.2016-12506.

Waldron, M. R., B. J. Nonnecke, T. Nishida, R. L. Horst, and T. R. Overton. 2003. Effect of lipopolysaccharide infusion on serum macromineral and vitamin D concentration in dairy cows. J. Dairy Sci. 86:3440-3446. https://doi.org/10.3168/jds.S0022-0302(03)73948 -4 .

Walther, A., M. Weihrauch, W. Schmidt, M. Gebhard, E. Martin, and H. Schmidt. 2000. Leukocyte-independent plasma extravasation during endotoxemia. Crit. Care Med. 28:2943-2948. https://doi .org/10.1097/00003246-200008000-00043.

Wilms, J., G. Wang, J. Doelman, M. Jacobs, and J. Martin-Tereso. 2019. Intravenous calcium infusion in a calving protocol disrupts calcium homeostasis compared with an oral calcium supplement. J. Dairy Sci. 102:6056-6064. https://doi.org/10.3168/jds.2018-15754.

Yuan, K., T. Liang, M. B. Muckey, L. G. D. Mendonça, L. E. Hulbert, C. C. Elrod, and B. J. Bradford. 2015. Yeast product supplementation modulated feeding behavior and metabolism in transition dairy cows. J. Dairy Sci. 98:532-540. https://doi.org/10.3168/jds $.2014-8468$.

Zarrin, M., O. Wellnitz, H. A. van Dorland, J. J. Gross, and R. M. Bruckmaier. 2014. Hyperketonemia during lipopolysaccharide-induced mastitis affects systemic and local intramammary metabolism in dairy cows. J. Dairy Sci. 97:3531-3541. https://doi.org/10 $.3168 /$ jds.2013-7480.

Zaworski, E. M., C. M. Shriver-Munsch, N. A. Fadden, W. K. Sanchez, I. Yoon, and G. Bobe. 2014. Effects of feeding various dosages of Saccharomyces cerevisiae fermentation product in transition dairy cows. J. Dairy Sci. 97:3081-3098. https://doi.org/10.3168/jds.2013 -7692 .

Zhang, B., H. Guo, W. Yang, M. Li, Y. Zou, J. J. Loor, C. Xia, and C. Xu. 2019. Effects of ORAI calcium release-activated calcium modulator 1 (ORAI1) on neutrophil activity in dairy cows with subclinical hypocalcemia. J. Anim. Sci. 97:3326-3336. https://doi .org/10.1093/jas/skz209. 